Dialectologia 22 (2019), 1-16.

ISSN: 2013-2247

Received 25 March 2017.

Accepted 16 July 2017.

\title{
THE COMPLEXITY OF PHONOLOGICAL CHANGE IN SOUTH HALMAHERA LANGUAGES
}

\author{
BURHANUDDIN ${ }^{1}$, SUMARLAM \& MAHSUN ${ }^{1}$ \\ Universitas Mataram, Indonesia ${ }^{1}$ * / Universitas Sebelas Maret, Indonesia * \\ burhanuddin.fkip@unram.ac.id / Sumarlamwd@gmail.com / mahsunirn@gmail.com
}

\begin{abstract}
Austronesian languages in South Halmahera, such as Buli, Maba, Sawai, Gebe, Gane and Taba, belong to South Halmahera-West New Guinea. This paper explains the stages and directions of sound change in these languages. Intensive and direct fieldworks in South Halmahera have been conducted to obtain data from these languages employing interview method, asking 200 basic vocabulary and 1000 cultural vocabulary. Data were analysed using top-down approach, through examining the complexity of phonological changes in the South Halmahera languages using Proto-Austronesia (PAN) and Proto-South Halmahera (PSH). The analysis revealed that change of PAN into South Halmahera languages can occur into, in average, four stages of change. Many PAN also can change into five, six, or seven stages of change, which can be considered as long and complex change. In addition, the tendency of change in each phase involves more than one alternatives of change. Moreover, the directions of change occur not only in homorganic (phonetically identical) and from voiced to voiceless consonants, but also from non-nasal to nasal, from $* \mathrm{i}>\mathrm{u}, *_{\mathrm{i}}>a,{ }^{*} \mathrm{u}>\mathrm{a}$. Each of the last three directions of change can occur otherwise.
\end{abstract}

\section{Keywords}

complexity, phonological change, top-down approach

\footnotetext{
* Language and Art Department, The Faculty of Teacher Training and Education, Universitas Mataram, Indonesia, Majapahit Street No. 62, Mataram, 83125 / The Faculty of Cultural Science, Universitas Sebelas Maret, Indonesia, Ir. Sutami Street No. 36A, Kentingan Jebres, Surakarta, West of Java, Indonesia.
} 


\section{LA COMPLEJIDAD DEL CAMBIO FONOLÓGICO EN LENGUAS DEL SUR DE HALMAHERA}

\section{Resumen}

Las lenguas austronesias en el sur de Halmahera, como Buli, Maba, Sawai, Gebe, Gane y Taba, pertenecen al sur de Halmahera-Oeste de Nueva Guinea. Este artículo explica las etapas y direcciones del cambio fónico en estos idiomas. Se han llevado a cabo trabajos de campo intensivos y directos en el sur de Halmahera para obtener datos de estas lenguas mediante el método de entrevista, preguntando 200 palabras de vocabulario básico y 1000 de vocabulario cultural. Los datos se analizaron utilizando un enfoque de arriba a abajo, a través del examen de la complejidad de los cambios fonológicos en las lenguas del sur de Halmahera utilizando el Proto-Austronesia (PAN) y el Proto-South Halmahera (PSH). EI análisis reveló que el cambio de PAN en lenguas del sur de Halmahera puede ocurrir, en promedio, en cuatro etapas de cambio. Muchas PAN también pueden cambiar a través de cinco, seis o siete etapas de cambio, lo que puede considerarse como un cambio largo y complejo. Además, la tendencia de cambio en cada fase implica más de una alternativa de cambio. Complementariamente, las direcciones del cambio se producen no solo en consonantes homorgánicas (fonéticamente idénticas) y de sonoras a sordas, sino también de no nasales a nasales, de $*_{\mathrm{i}}>\mathrm{u}, *_{\mathrm{i}}>a, *_{\mathrm{u}}>\mathrm{a}$. Cada una de las últimas tres direcciones de cambio puede producirse de otro modo.

\section{Palabras clave}

complejidad, cambio fonológico, enfoque de arriba a abajo

\section{Introduction}

Blust (1978: 181-234) and Kamholz (2014: 1) grouped Austronesian (AN) languages in South Halmahera, the Province of North Maluku, Indonesia, into South HalmaheraWest New Guinea, which is one of the four main branches of Malayo-Polinesian languages (West Malayo-Polinesia, Central Malayo-Polinesia, South Halmahera-West New Guinea, and Oceania) (Blust 1983/1984: 1, 1993: 245-279, 2013: 30-33). Many Austronesian historical linguists nowadays have used this grouping as a reference for investigating Autronesian languages.

According to Blust (1978: 182) South Halmahera languages comprise Buli, Maba, Sawai, Patani, Gane and Taba languages. Based on the dialectometric computation, Badan Bahasa (2014: 119-131) identified that Maba and Patani are dialects of one language, rather than as a separate language, indicated by them revealing $75.25 \%$ 
etymological difference. Thus, this research picked up Maba rather than Patani as an object. Kamholz (2014: 133-134) included Gebe as part of Maba and Patani because they share prefix $\{f-\}$ as a subject marker for the second plural pronoun. To reveal the complexity of sound change from the Proto-Austronesia (PAN) and Proto-South Halmahera (PSH) into South Halmahera languages, this research included six languages: Buli (BI), Maba (Mb), Sawai (Sw), Gebe (Gb), Gane (Gn) and Taba (Tb).

Studies on Austronesian languages in west parts of Indonesia indicated that sound change in these languages is relatively less complex, involving two to three stages of change. It is scarce to evidence four to six changes. For example, in Sasak (one of west Austronesian languages), change of PAN: *naSik 'to ascend' to *taek involves two stages of change: *naSik (sinkop) > *naik (partial assimilation, lowering vowel) > *taek. More common change appears in PAN *duSa 'dua [two]' in Javaness language: loro, which includes five stages of change from *duSa 'two' (sinkop) $>$ *dua $>$ *rua (contraction) > $*_{\text {ro }}$ (reduplication) $>$ *roro $($ dissimilation $)>*$ loro. However, such long stage of change is not common in west Austronesian languages in Indonesia. Little is known about stages of change in South Halmahera languages which is the main concern of the first part of this paper.

Besides the above difference, sound change in Austronesian languages in West part of Indonesia follow ordinary rules. For examples, *u $>0$ or $\hat{o}, * i>e$ or $\hat{e}$, and $*^{*}>e$, $\hat{e}, o$, or $\hat{o}$. In addition, considering the Proto-Austronesia (PAN) vowels which consist of $i$, $u, \partial$, and $a$, all mid vowels can be assumed to derive from high and low vowels. For example, PAN *Rəbun 'jump into water', in Sumbawa language (one of west Austronesian languages), change into: *rabôn, through *Rəbun > *rəbun (lowering vowel $*_{u}>/$ ô/) $>*^{*}$ rabôn. This also applies for consonants. Consonant change in West Austronesian languages occur in homorganic (phonetically identical) dan from voiced to voiceless consonants, such as change from ${ }^{*} \mathrm{~d}>t,{ }^{*} \mathrm{~b}>p,{ }^{*} \mathrm{p}>f,{ }^{*} \mathrm{f}>h,{ }^{*} \mathrm{~h}>\emptyset,{ }^{*} \mathrm{mb}>b$, ${ }^{*}$ nt $>t, *^{*}$ d $>d$, and so on, which are relatively easy to detect. The second part of this paper addresses and explains whether South Halmahera language tends to follow these patterns or otherwise.

The above elaboration suggests that the concept of 'complexity' refers to both 'stages' and 'directions' of sound change. Stages of change refer to the length or a 
number of stages through which sound changes appear. The longer the stage of change, the more complex the process involves. This rule applies otherwise. Likewise, if sound change to follow common patterns of change, the sound change involves simple process. Otherwise, if the change reveals bizarre, unpredicted changes, it is considered as a complex change.

\section{Methodological Framework}

To provide explanation about the issues above, linguistic data had been collected using documentation and interview methods. Documentation method was used to collect Proto-Austronesia (PAN), reconstructed by Blust \& Trussel (2014) in Blust's Austronesian Comparative Dictionary, and Proto-South Halmahera (PSH) reconstructed by Burhanuddin (2016). Interview method was employed to gather 200 basic vocabulary (revised Blust 1980) and 1000 cultural vocabulary on six languages in South Halmahera, including Buli, Maba, Sawai, Gebe, Gane and Sawai languages. Data were analysed using top-down approach, through examining the complexity of sound changes in the South Halmahera languages using Proto-Austronesian (PAN) and Proto-South Halmahera (PSH).

\section{The complexity of sound change in South Halmahera Languages}

\subsection{Complexity of sound change process}

To explain the complexity of phonological change stages in South Halmahera languages, 117 PAN etymons have been used because these etymons have been considered to be inherited into South Halmehera languages. Meanwhile, other PAN etymons were excluded because they have strong lexical differences by which tracking the process of sound change from these etymons is not robust. Moreover, PAN etymons which remain intact in the current South Halmahera languages (not having any change) 
were not considered as data and therefore discarded for analysis. For example, PAN *gilin 'to mill' > Sw: gilin. The following chart shows the process and accumulation of phonological change.

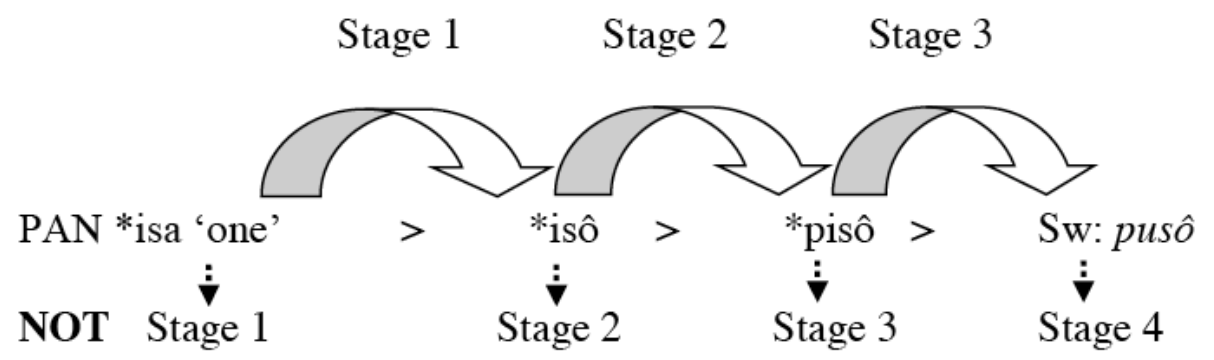

Chart 1. The accumulation concept of phonological change of stage

Phonological change of PAN *isa 'one' into Sawai: *pusô, involves three, not four, stages of change.

From 117 PAN etymons, there are 437 artifacts with a few sound modifications, inherited into six languages in South Halmahera (Buli, Maba, Sawai, Gebe, Gane and Taba). Considering the number of etymons used and language spoken in South Halmahera, PAN can be revealed into 702 artifacts. However, since some PAN etymon was not always inherited into one of South Halmahera languages and their artifacts in these languages and thus are claimed to be different lexicons, they were not analysed.

Based on the computation, there are several stages of change in South Halmahera languages. There are $2.71 \%$ of PAN etymons that have undergone only one cycle of change, as shown in the example 1.

(1)

$\begin{array}{lll}\text { Gloss } & \text { PAN } & \\ \text { one } & *_{\text {isa }} & >\text { Bl: pisa } \\ \text { I } & \text { *aku } & >\text { Mb: au } \\ \text { cry } & \text { *Cangis } & >\text { Bl, Mb, Gn: tanis } \\ \text { flower } & \text { *buna } & >\text { Gb: bunan } \\ \text { this } & *_{\text {ini }} & >\text { Tb: inê, etc. }\end{array}$


There are $13.27 \%$ of PAN etymons that have undergone two stages of change into South Halmahera languages, as shown in the example 2.

(2)

\begin{tabular}{|c|c|c|c|}
\hline Gloss & PAN & & \\
\hline I & *aku & $>* a k$ & $>$ Gn, Tb: yak \\
\hline wake up & *banun & $>*^{*}$ anun & $>$ Gn, Tb: payin \\
\hline coconut fibre & *bunut & $>$ *punut & $>\mathrm{Bl}, \mathrm{Gn}$ : punit \\
\hline grand child & *bubu & $>*$ buu & $>\mathrm{BI}: b u$ \\
\hline hand & *kamay & > *kamô & > Tb: kômô, etc. \\
\hline
\end{tabular}

There are $23.8 \%$ of PAN etymons that have undergone three stages of change into South Halmahera languages, as shown in the example 3.

(3)

\begin{tabular}{|c|c|c|c|c|}
\hline Gloss & PAN & & & \\
\hline die & *aCay & $>$ *atay & $>*^{*}$ matay & $>\mathrm{Bl}: m a t$ \\
\hline cry & *Canis & $>*$ tanis & $>*_{\text {tenis }}$ & > Gb: tenis \\
\hline know & *Ca?u & $>*$ ta?u & $>*$ tau & $>\mathrm{Bl}:$ to \\
\hline $\operatorname{six}$ & *ənəm & > *ənam & $>*^{*}$ onam & > BI: woman \\
\hline gum & *gusi & $>*_{\text {gosi }}$ & $>*_{\text {goi }}$ & > Bl: igo, etc. \\
\hline
\end{tabular}

There are $23.11 \%$ of PAN etymons that have undergone four stages of change into South Halmahera languages, as shown in the example 4.

(4)

\begin{tabular}{|c|c|c|c|c|}
\hline Gloss & PAN & & & \\
\hline \multirow[t]{2}{*}{ or } & *baran & $>$ *bara & $>*$ para & $>*$ pa \\
\hline & & $>\mathrm{Tb}: p a$ & & \\
\hline \multirow[t]{2}{*}{ cucumber } & *?atimun & > *?atimin & $>*$ atimin & $>*_{\text {timin }}$ \\
\hline & & > BI: titimin & & \\
\hline \multirow[t]{2}{*}{ worn } & *kulay & $>*_{\text {kula }}$ & $>$ *kulat & $>*_{\text {gulat }}$ \\
\hline & & > Bl: gugulat & & \\
\hline \multirow[t]{2}{*}{ centipede } & *Sipan & $>*$ lipan & $>*^{l i p i n}$ & $>*^{*}$ lipin \\
\hline & & > Bl: lifin & & \\
\hline \multirow[t]{2}{*}{ eight } & *walu & $>*$ wal & $>$ *wawal & $>*_{\text {pawal }}$ \\
\hline & & > BI: pôwal, etc. & & \\
\hline
\end{tabular}


There are $18.99 \%$ of PAN etymons that have undergone five stages of change into South Halmahera languages, as shown in the example 5.

(5)

\begin{tabular}{|c|c|c|c|c|c|}
\hline Gloss & PAN & & & & \\
\hline \multirow[t]{2}{*}{ blood } & *daRa? & $>*$ daa? & $>* d a ?$ & $>$ *la? & $>$ *laf \\
\hline & & $>$ Bl: laflaf & & & \\
\hline \multirow[t]{2}{*}{ swelling } & *baRə? & > *baə? & $>$ *baə & $>*$ bo & $>$ *bos \\
\hline & & $>\mathrm{Sw}, \mathrm{Tb}:$ mbos & & & \\
\hline \multirow[t]{4}{*}{ earthquake } & *lindDuR & $>* \operatorname{lin} \mathrm{Du}$ & $>* \operatorname{linu}$ & $>*^{*} \sin u$ & $>*$ siu \\
\hline & & > Bl, Gb, Gn: sui & & & \\
\hline & & $>* \operatorname{lin} \mathrm{Du}$ & $>* \operatorname{linu}$ & $>* \sin u$ & $>* \operatorname{siu}$ \\
\hline & & $>\mathrm{Tb}: s u$ & & & \\
\hline \multirow[t]{4}{*}{ bitter melon } & *paria? & $>$ *pari? & $>*$ pari & $>*$ pare & $>$ *papare \\
\hline & & > BI: papare & & & \\
\hline & & $>$ *pari? & $>*$ pari & $>*$ pare & $>$ *papare \\
\hline & & > Gb: pupare & & & \\
\hline \multirow[t]{4}{*}{ how much } & *pica & $>{ }^{*}$ pisa & $>*$ fisa & $>*$ fis & $>*_{\text {fifis }}$ \\
\hline & & $>$ Mb: iffis, dsb. & & & \\
\hline & & $>*^{*}$ isa & $>*$ fisa & $>*_{\text {fis }}$ & $>*_{\text {fifis }}$ \\
\hline & & > Sw: faifis, etc. & & & \\
\hline
\end{tabular}

There are $12.36 \%$ of PAN etymons that have undergone six stages of change into South Halmahera languages, as shown in the example 6.

(6)

\begin{tabular}{|c|c|c|c|c|c|}
\hline \multirow{2}{*}{$\begin{array}{l}\text { Gloss } \\
\text { to pin }\end{array}$} & \multicolumn{5}{|l|}{ PAN } \\
\hline & *suksuk & $>*$ tuksuk & $>*_{\text {tusuk }}$ & $>*$ tuuk & $>*$ tuk \\
\hline & & $>*$ mtuk & $>\mathrm{Mb}: m t u$ & & \\
\hline \multirow[t]{2}{*}{ go } & *paNaw & $>*$ panaw & $>*^{*}$ an & $>*$ fan & > *fên \\
\hline & & > *fêfên & > Gb: yêfên & & \\
\hline \multirow[t]{2}{*}{ four } & *Səpat & $>*_{\text {sipat }}$ & $>*_{\text {pipat }}$ & > * pipôt & $>$ *pifôt \\
\hline & & $>$ *pfôt & $>\mathrm{Tb}:$ phot & & \\
\hline \multirow[t]{2}{*}{ blow } & $*_{\text {tiyup }}$ & $>*$ tiup & $>*$ tiuf & $>*_{\text {iuf }}$ & $>*$ uf \\
\hline & & $>*$ ufa & > Bl: ufa? & & \\
\hline \multirow[t]{2}{*}{ roof } & *?atəp & > *?atap & $>$ *atap & $>*$ ataf & $>$ *ôtaf \\
\hline & & $>*$ ôtas & > Mb: ôtas, & & \\
\hline
\end{tabular}


There are $3.2 \%$ of PAN etymons that have undergone seven stages of change into South Halmahera languages, as shown in the example 7.

(7)

\begin{tabular}{|c|c|c|c|c|c|}
\hline Gloss & PAN & & & & \\
\hline \multirow[t]{2}{*}{ blow } & $*_{\text {tiyup }}$ & $>*$ tiup & $>*$ tiuf & $>*$ iuf & $>*$ uf \\
\hline & & $>*$ ufa & $>*$ ufa? & $>$ Gb: nufa? & \\
\hline \multirow[t]{2}{*}{ breath } & *NiSawa & $>*$ Niawa & $>$ *Nawa & $>*$ nawa & $>*^{*}$ nawa? \\
\hline & & > *nawô? & > *nôwô? & > Tb: manôwô? & \\
\hline \multirow[t]{2}{*}{ wash (hand) } & *SuraS & $>*$ SuaS & $>*$ uas & $>*$ uas & $>*$ uwas \\
\hline & & > *uwôs & > *wôs & > Gn: awôs & \\
\hline \multirow[t]{2}{*}{ nephew } & *kamanak & $>$ *kafanak & $>$ *kfanak & $>$ fanak & $>$ fanok \\
\hline & & $>$ fonok & $>*_{\text {fonuk }}$ & Sw: fonug & \\
\hline \multirow[t]{2}{*}{ flood } & *baSa? & $>$ *basa? & $>$ *pasa? & $>*$ pasa & $>*$ pas \\
\hline & & $>*_{\text {pis }}$ & $>*$ pipis & $>\mathrm{Bl}, \mathrm{Mb}, \mathrm{Gb}:$ ipi & tc. \\
\hline
\end{tabular}

There are $2.06 \%$ of PAN etymons that have undergone eight stages of change into South Halmahera languages, as shown in the example 8.

(8)

\begin{tabular}{|c|c|c|c|c|c|}
\hline Glos & PAN & & & & \\
\hline \multirow[t]{2}{*}{ cheek } & *pipih & $>$ *pipi & > *pipo & $>$ *popo & $>*$ pofo \\
\hline & & $>*_{\text {fofo }}$ & $>*_{\text {foho }}$ & $>$ *hoho & Tb: oho \\
\hline \multirow[t]{2}{*}{ flat } & *dataR & $>*$ data & $>*$ ata & $>*_{\text {ta }}$ & $>*$ tô \\
\hline & & $>$ *tôl & > *tôlô & > *tôlôn & > Mb: ntôlôn \\
\hline \multirow[t]{2}{*}{ flood } & *baSa? & $>$ *basa? & $>$ *pasa? & $>$ *pasa & $>*$ pas \\
\hline & & $>*_{\text {pis }}$ & $>*$ pipis & > *kipis & $\begin{array}{l}>\text { Gn: kiwis } \\
>\text { Tb: kihis, etc }\end{array}$ \\
\hline
\end{tabular}

There are $0.46 \%$ of PAN etymons that have undergone nine stages of change into South Halmahera languages, as shown in the example 9.

(9)

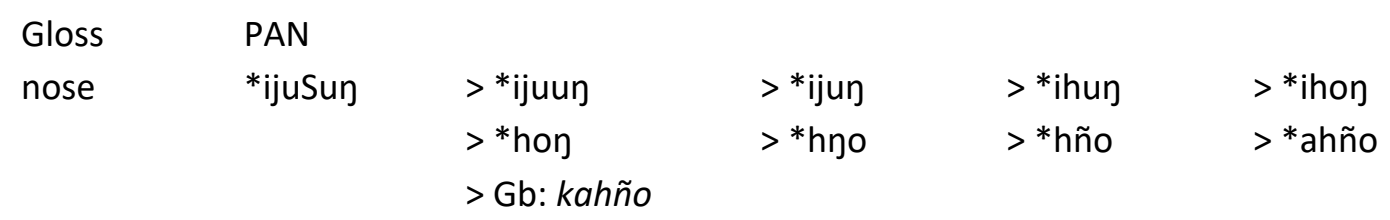


Based on the calculation of stages of change, it was found that phonological change from PAN etymons into South Halmahera languages occur, in average, in four stages and that the number of etymons that change into five, six, or seven stage are considerable lot (see graph 1). These findings suggest that sound change in these languages takes complex and long process.

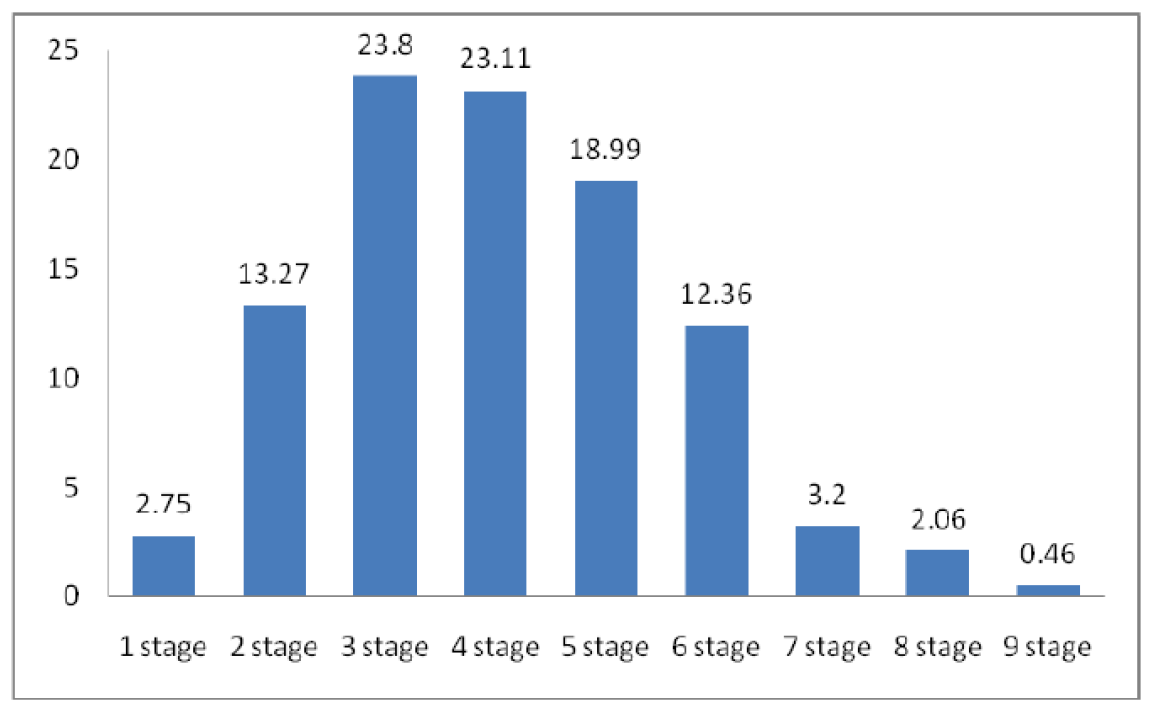

Graph 1. Proportion of the Stage of Phonological Change in South Halmahera Languages

The complexity of Phonological change in South Halmahera languages is not only associated with the length of the change but also uncertainty to the change mechanism. This can be interpreted that the two-stage change can occur in several change alternatives. Likewise, three-stage or four-stage change are expected to change in a number of change alternatives, as exemplified in 10, 11a-c, and 12.

$\begin{array}{cl}\text { Alternatives } & \text { Gloss } \\ 1 & \text { wake up } \\ 2 & \\ & \\ 1 & \text { ridge } \\ 2 & \end{array}$

\section{PAN}

$\begin{array}{lll}\text { *bajun } & >\text { *panun } & >\mathrm{Gn}, \mathrm{Tb} \text { : panin } \\ & >\text { *banin } & >\mathrm{Gn}, \mathrm{Tb} \text { : panin } \\ \text { *bubunan } & >\text { *pubunan } & >\mathrm{Bl} \text { : pupunan } \\ & >\text { *bupunan } & >\mathrm{Bl} \text { : pupunan }\end{array}$




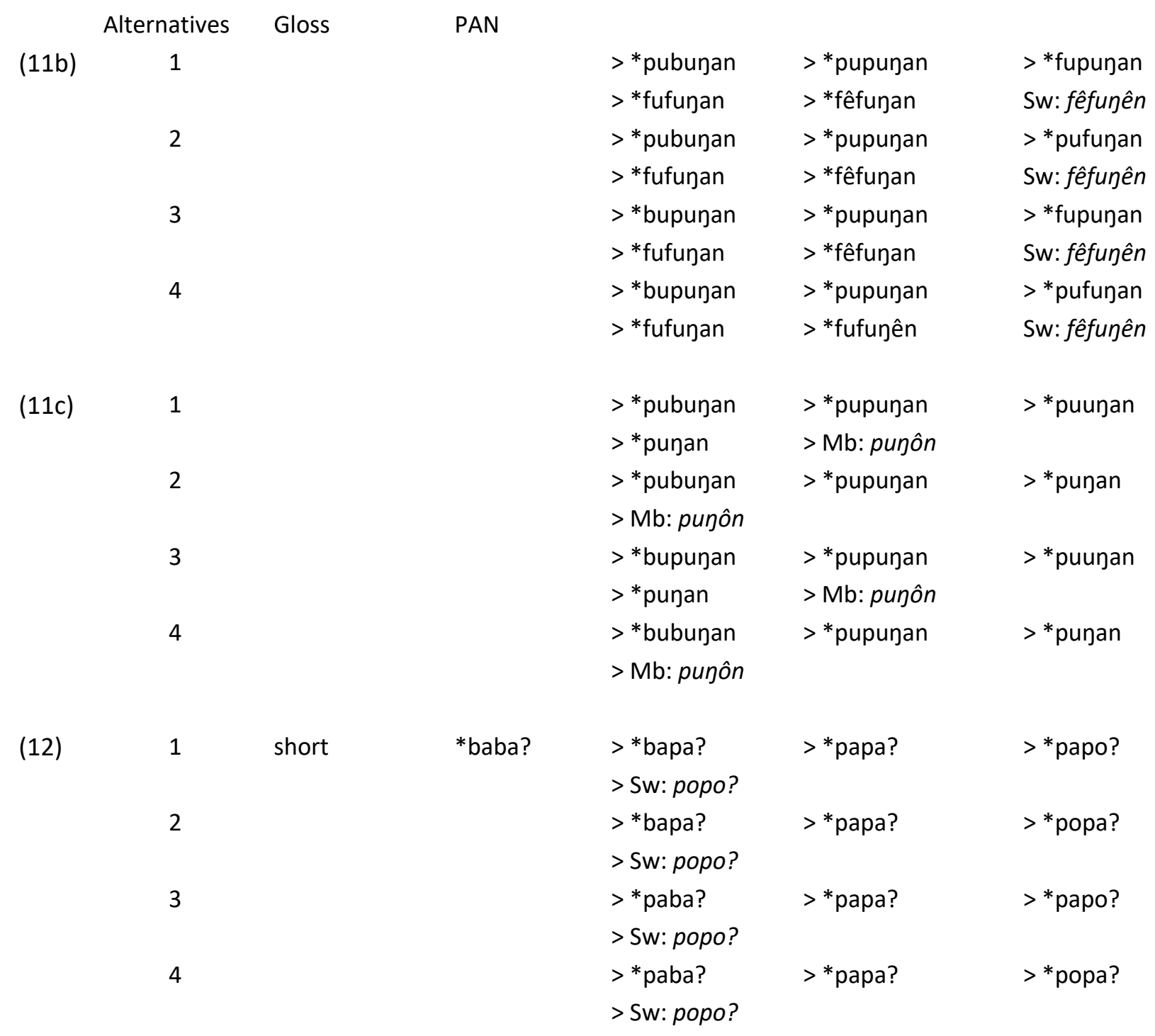

Examples 10, 11a-c, and 12 show unrelated patterns of phonological change from one alternative to another. Hence it is quite challenging to determine which changes that possibly occur. There are some explanations to be offered to understand this issue. Firstly, understanding the tendency toward the types of phonological change in these languages. If PAN * $u$ as ultima regularly changes to /i/ in Gane and Taba (as shown in example 10), change of $*^{*} \mathrm{u}>i$ precedes $* \mathrm{~b}>p$, thus PAN *banun $>*_{\text {banin }}>\mathrm{Gn}, \mathrm{Tb}$ : panin (alternative 2). This appropriate explanation because regular change requires long terms to create, thus sound change is assumed to occur early. On the other hand, if change of ${ }^{*} \mathrm{u}>$ /i/ happens sporadically, change of ${ }^{*} \mathrm{~b}>p$ might occur in advance because this belongs to universal change from voiced to voiceless. This reveals the first alternative change, from PAN *banun $>$ *panun $>\mathrm{Gn}$, Tb: panin (alternative 1). If 
progressive assimilation is more likely to be happened than regressive assimilation, as shown in example 11a-c and 12, alternatively, *pubunan > *pupunan and *paba? > * papa? are more expected to be revealed than *bupunan $>$ *pupunan dan *bapa? > papa?, and vice versa. If reduplication is common or seen regularly, the omission of the first syllable, i.e *pupunan > * punan > Mb: punôn, is more likely to occur than *pupunan (sinkop) *puunan > Mb: punôn.

Secondly, understanding the general characteristics of Austronesian languages which mostly comprise two syllables. Hence, word with more than two syllables tend to undergo fusion (vowel or consonant), or even omission of the first syllable. This justifies that change from PAN *bubunan $>$ *pubunan, *fupunan $>$ *fufunan, *fufunan $>$ *fêfunan, is more likely to happen than PAN *bubunan > *bupunan, *pufunan > *fufunan, *fufunan $>$ *fufunên. Understanding these aspects will eradicate (or minimize) slips in determining the process of phonological change in South Halmahera languages.

Phonological change in South Halmahera languages can happen in one alternative of change, as exemplified in 13.

\begin{tabular}{|c|c|c|c|c|c|}
\hline Gloss & PAN & & & & \\
\hline grand child & *bubu & $>*$ buu & $>\mathrm{Bl}: b u$ & & \\
\hline raft & *dakit & $>*_{\text {dait }}$ & $>$ Tb: dat & & \\
\hline cry & *Canis & $>*$ tanis & > Sw: tanês & & \\
\hline year & *CawiN & $>*_{\text {tawiN }}$ & $>*_{\text {tawin }}$ & $>*$ tawun & $\begin{array}{l}>\mathrm{Bl}, \mathrm{Mb}, \mathrm{Sw}, \mathrm{Gb} \text {, } \\
\mathrm{Gn} \text { : taun }\end{array}$ \\
\hline spittle & *dula? & $\begin{array}{l}>* \text { dila? } \\
>*_{\text {tif }}\end{array}$ & $\begin{array}{l}>{ }^{*} \text { tila? } \\
>* \text { titif }\end{array}$ & $\begin{array}{l}>*_{\text {tia? }} \\
>\text { Bl: itif }\end{array}$ & $>*$ ti? \\
\hline nose & *ijuSun & $\begin{array}{l}>*_{\text {ijuun }} \\
>*_{\text {hon }} \\
>\text { Gb: } k a h r\end{array}$ & $\begin{array}{l}>*_{\text {ijun }} \\
>\text { *hyo }^{-}\end{array}$ & $\begin{array}{l}>*_{\text {ihun }} \\
>\text { *hño }\end{array}$ & $\begin{array}{l}>* \text { ihon } \\
>* \text { ahño }\end{array}$ \\
\hline
\end{tabular}

\subsection{Complexity of directions of sound change}

The analysis revealed that vowel changes in South Halmahera languages are not only occurred from $* \mathrm{i}>e, *_{\mathrm{u}}>0$, and ${ }^{*} \mathrm{a}>\mathrm{e}$ or 0 , but also from ${ }^{*} \mathrm{u}>i$ or otherwise, from 
$*_{a}>i$ or $u$, or otherwise, and from $*^{*}>u$ or $i$, or otherwise. Change from vowel $*^{*}>i$, or otherwise is a common change in South Halmahera languages, because this change happens regularly. Meanwhile, change from vowel *a $>i$ or $u$, and from ${ }^{*} \partial>i$ or $u$ are found to be relatively limited and occurred sporadically.

Change from PAN $* u>i$ into South Halmahera languages happens through assimilation-dissimilation process. However, direct change, without assimilation, sometimes observed, as indicated in the example 14.

\begin{tabular}{|c|c|c|}
\hline Gloss & PAN & \\
\hline \multirow[t]{2}{*}{ lice } & *kutu & $>*^{*}$ kut $>*^{*}$ kit $>M b:$ it \\
\hline & & $>*$ kut $>$ Sw: kit \\
\hline \multirow[t]{2}{*}{ bird } & *manuk & $>$ Gn: manik \\
\hline & & $>$ *manu > Bl, Mb, Gb: mani \\
\hline wake up & *banun & $\begin{array}{l}>* \text { panun }>* \text { panin }>* \text { panil }>* \text { palin }> \\
\quad \text { Mb: mpanil }\end{array}$ \\
\hline grand child & *bubu & $>*^{*}$ buu $>*$ bu $>*$ bi $>*$ bi? $>* a b i ?>M b: a b b i ?$ \\
\hline & & $>*^{*}$ buu $>*^{*}$ bu $>*$ bi $>$ Sw: bi? \\
\hline
\end{tabular}

Examples 15 and 16 provide changes that involve assimilation and dissimilation process, respectively, for PAN *u to become $i$. In addition, example 16 shows both assimilation and dissimilation process. In South Halmahera, changes process in 14, 15, and 16 is regular.

\begin{tabular}{|c|c|c|}
\hline Gloss & PAN & \\
\hline (15) to drink & *inum & $>*_{\text {inim }}>$ Gn, Tb: imin \\
\hline \multirow[t]{2}{*}{ cucumber } & *?atimun & $>{ }^{*}$ ?atimin $>*$ atimin $>*^{*}$ timin $>\mathrm{Mb}$ : tinim \\
\hline & & $>*$ ?atimin $>*$ atimin $>*$ timin $>$ Bl: titimin \\
\hline \multirow[t]{3}{*}{ coconut } & *ñiuR & $>{ }^{*} \tilde{n} i u>*^{*}$ niu $>$ *niwu $>$ Mb, Gn, Tb: niwi \\
\hline & & $>*_{\tilde{n}} \mathrm{iu}>*^{\text {niu }}>*^{*}$ niwu $>$ Sw: niwê \\
\hline & & $>*^{n}$ iu $>*^{*}$ niu $>$ *niwu $>$ *niwi $>$ Gb: niwi? \\
\hline gum & *gusi & $>^{*}$ gisi > Sw, Gn, Tb: nisi \\
\hline \multirow[t]{2}{*}{ (16) coconut fibres } & *bunut & $>$ *punut $>\mathrm{BI}, \mathrm{Gn}$ : punit \\
\hline & & $>*_{\text {punut }}>*_{\text {punit }}>\mathrm{Mb}$ : pinit \\
\hline \multirow[t]{3}{*}{ moss } & *lumut & > *lumit > BI: lulumit \\
\hline & & $>$ *lumit $>$ *limit > Mb: limlimit \\
\hline & & $>*$ lumit $>*$ lumlumit $>$ Gb: limlumit \\
\hline
\end{tabular}


Dialectologia 22 (2019), 1-16.

ISSN: 2013-2247

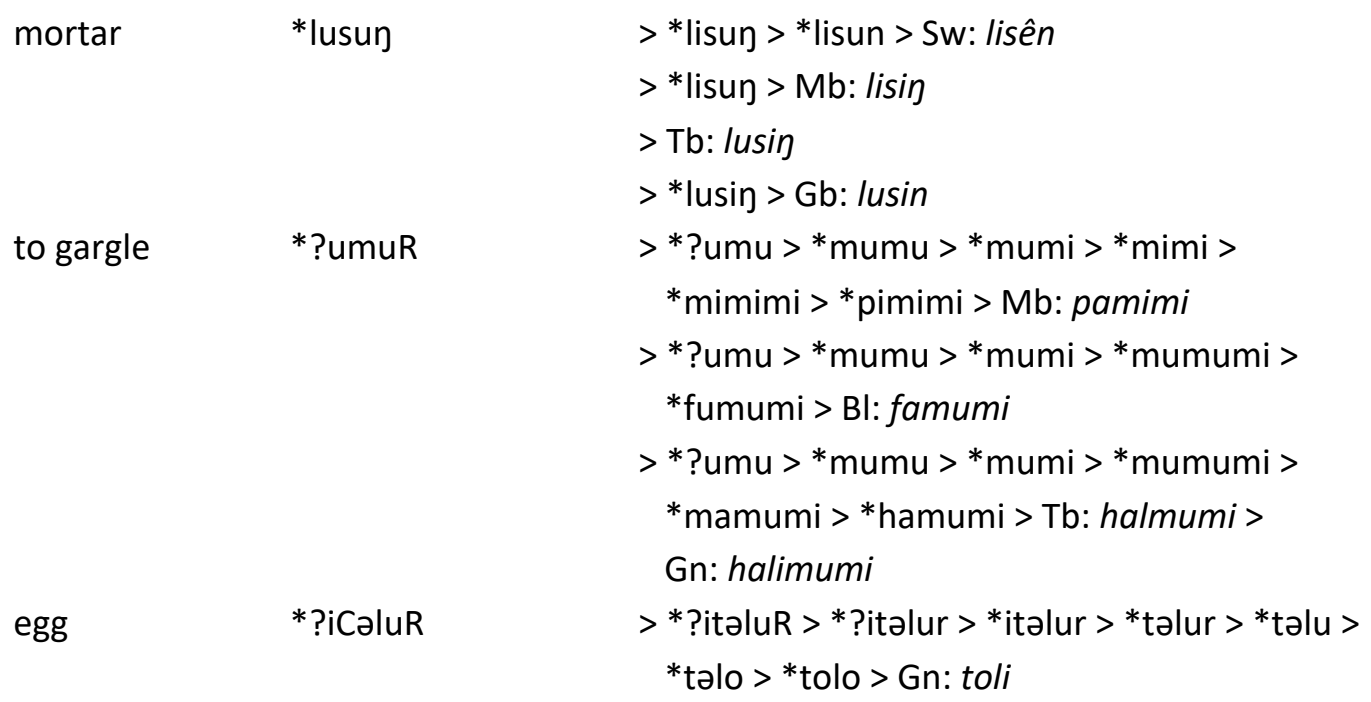

Like PAN $*_{u}>i$, PAN $*_{i}>u$ occurs either directly or through assimilationdissimilation process. Direct change from vowel PAN $*_{i}>u$ can be observed in example 17, while assimilation and dissimilation process are exemplified in 18 and 19, respectively. Assimilation and dissmilation for vowel PAN $*_{i}>u$ is a common in these languages.

\begin{tabular}{|c|c|c|c|}
\hline & Gloss & PAN & \\
\hline (17) & year & *CawiN & $\begin{array}{l}>*_{\text {tawiN }}>* \text { tawin }>* \text { tawun }>\text { Bl, Mb, Sw, Gb, } \\
\quad \text { Gn, Tb: taun }\end{array}$ \\
\hline & smooth & *dalis & $>*$ dalus > Mb, Sw, Gn: nalus \\
\hline & & & $>*$ dalus $>$ Gb, Tb: alus \\
\hline (18) & cheek & *pipih & $\begin{array}{l}>*_{\text {pipi }}>* \text { pipu }>* \text { pôpu }>* \text { pôfu }>* \text { fôfu }> \\
\text { Mb: fôfur }\end{array}$ \\
\hline (19) & to mill & *gilin & $>*$ gulin > Gn: gulinan \\
\hline
\end{tabular}

PAN *a $>i$ can be observed through dissimilation process, exemplified in 20 . Meanwhile, change PAN *a > $u$ can occur through either dissimilation process shown in 22 or direct change as in example 21.
Gloss
PAN
(20) or
*baran
flood
*baSa?

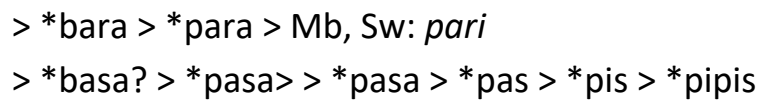




\begin{tabular}{|c|c|c|}
\hline & & > Bl, Mb, Gb: ipis \\
\hline & & $>*^{*}$ basa? $>*_{\text {pasa}}$ ? $>*_{\text {pasa }}>{ }^{*}$ pas $>*_{\text {pis }}>*_{\text {pipis }}>$ \\
\hline & & *pipês > Sw: kipês \\
\hline & & $>*_{\text {basa}}$ ? $>*_{\text {pasa }}$ ? $>*_{\text {pasa }}>*_{\text {pas }}>*$ pis $>$ pipis \\
\hline & & > *kipis > Gn: kiwis, Tb: kihis \\
\hline \multirow[t]{2}{*}{ stick } & *balbal & $>*_{\text {baltal }}>*_{\text {taltal }}>*_{\text {tatal }}>*_{\text {tital }}>$ Bl: titial \\
\hline & & $>*_{\text {baltal }}>*_{\text {taltal }}>*_{\text {tiltal }}>\mathrm{Mb}:$ tiltil \\
\hline \multirow[t]{2}{*}{ to marry } & *?asawa & $>$ *?asaw $>$ *?isaw $>$ *?isôw $>$ Mb: pisôw \\
\hline & & $>*$ ?asaw $>*$ ? isaw $>*$ ? isow $>$ Tb: isow \\
\hline \multirow[t]{2}{*}{ nine } & *siwa & $>*^{*} \operatorname{siwu}>{ }^{*}$ siyu $>\mathrm{Gb}$ : isiyu \\
\hline & & $>*^{*} \operatorname{siwu}>* \operatorname{siu}>\mathrm{Gn}: p \operatorname{siu}$ \\
\hline stick & Balbal & $>*$ baltal $>*$ taltal $>*$ taltul $>$ Tb: taltula \\
\hline
\end{tabular}

Finally, PAN $*_{\partial}>\mathrm{u}$ in South Halmahera languages can be proceeded directly (example 23). Meanwhile, PAN *ə > $i$ can be proceeded through assimilation (24).

\begin{tabular}{|c|c|c|c|}
\hline & Gloss & PAN & \\
\hline (23) & one meter & *dəpa & $>$ *dupa $>$ *lupa $>$ *lupô $>$ *lufô $>$ Sw: lufsô \\
\hline (24) & wee & *kəmi? & $>{ }^{*}$ kəmi $>{ }^{*}$ məmi > Mb: mimi \\
\hline
\end{tabular}

Consonant changes in South Halmahera languages are relatively unusual. For instance, PAN *k $>t$ or $b$, exemplified in 25 and 26 , in sequence.

\footnotetext{
Gloss PAN

(25) wee

*kəmi?

$>{ }^{*}$ kəmi $>*$ təmi $>$ Sw: temi

$>$ *kəmi? > təmi? > Gb: tami?

(26) clean

${ }^{*}$ kərsik $\quad>{ }^{*}$ kərsi $>$ Gb: barsi

$>$ *kərsi > *bərsi > Gn: bersi > Sw: mbersi

Employing Proto-South Halmahera (PSH), reconstructed by Burhanuddin (2016), it was found that there is a change from nonnasal to nasal, such as PSH ${ }^{*} t / \#->m$ in 27 , and $\mathrm{PSH}{ }^{*} \mathrm{k} /-\#>m$ as shown in 28 , both of which are changed through assimilation process.
} 


\begin{tabular}{|c|c|c|c|}
\hline & Gloss & PSH & \\
\hline (27) & to see & *tem & > *têm > Bl: mêm \\
\hline & wee & *patimi? & $>*_{\text {patimi }}>*_{\text {ptimi}}$ /*atimi? $>*$ timi? \\
\hline & & & $>*$ patimi $>*$ panimi $>$ Bl: panami \\
\hline (28) & dumb & *kamouk & $>$ *kamou $>$ *kamôu $>$ *mamôu $>$ Bl: \\
\hline & & & $>*$ kamou $>*$ kameu $>*$ kimou $>\mathrm{Mb}:$ \\
\hline & In ado & hange al & n be observed from nonsemivowe \\
\hline as PS & $\mathrm{H}^{*} \mathrm{k}$ a & $\#->w$, as & nplified in 29 and $30 . \mathrm{PSH}^{*} \mathrm{~d}$ and * \\
\hline 31 an & d 32 . & & \\
\hline & Gloss & PSH & \\
\hline (29) & pot & *kulan & $>$ Bl: wulan \\
\hline (30) & $\operatorname{six}$ & *ponam & > *pônam > Bl: wônam \\
\hline & & & > *pônam > *wônam > Mb: wônôm \\
\hline & & & > *pônam > *woman > Sw: wônam \\
\hline (31) & raft & *dat & $>*$ dêt > Sw: yêt \\
\hline (32) & salt & *gasi? & $>*^{*}$ gasin > Tb: yasin \\
\hline
\end{tabular}

Moreover, $\mathrm{PSH}^{*}$ ? (glottal)/ -\# >n, is regularly changed, as indicated in 33 .

(33)

\begin{tabular}{|c|c|c|}
\hline Gloss & PSH & \\
\hline \multirow[t]{3}{*}{ corner } & *kasu? & $>$ *sasu? > BI: sasun \\
\hline & & $>$ *asu? $>*$ su? $>\mathrm{Mb}$ : sun \\
\hline & & $>$ *kəsu? > *səsu? > Sw: sěsun \\
\hline starfruit & *balimbi? & > Tb: balimbin \\
\hline salt & *gasi? & > *yasi? > Tb: yasin \\
\hline
\end{tabular}

\section{Conclusion}

Complexity of phonological change in South Halmahera languages is associated with three aspects, including (a) the length of the stages or process of change, (b) 
multiple ways (alternatives) of change, and (c) directions of change. These aspects become the distinguished historical, linguistic markers between South Halmahera languages and other Austronesian languages in west parts of Indonesia. Description about other distinctive markers requires other studies to explore different linguistic aspects of these languages.

\section{References}

BAdAN BAHASA (2014) Bahasa dan Peta Bahasa di Indonesia, Jakarta: Department Pendidikan Nasional.

BLUST, Robert A. (1978) "Eastern Malayo-Polynesian: a Subgrouping Argument", Pacific Linguistics, Series C 61, 181-234.

BLUST, Robert A. (1980) "Early Austronesian Social Organization the Evidence of Language", Current Anthropology 21(2), 205-266.

BLUST, Robert A. (1983/1984) "More on the Position of the Languages of Eastern Indonesia", Oceanic Linguistics 22/23, 1-28.

BLust, Robert A. (1993) “Central and Central-Eastern Malayo-Polynesian”, Oceanic Linguistics 32, 241-293.

BLUST, Robert A. (2013) The Austronesian Languages, Revised Edition, Canberra: Pacific Linguistics.

BLUST, Robert A. \& S. TRUSSEl (2014) "Blust' Austronesian Comparative Dictionary", available online at $\langle w w w$.trussel2.com/ACD $\rangle$.

BURHANUDDIN (2016) "Hubungan Kekerabatan Bahasa-Bahasa Subrumpun Halmahera Selatan di HHalmahera Selatan", Disertasi S3, Surakarta: Universitas Sebelas Maret.

KamHolz, David Christopher (2014) Austronesians in Papua: Diversification and Change in South HHalmahera-West New Guinea, Disertasi for Doctor of Philosophy, Berkeley: University of California. 